\title{
Interpelacja poselska do prezesa Rady Ministrów w sprawie strategii polskiej polityki energetycznej w perspektywie do roku 2050
}

\author{
Parliamentary question to the Prime Minister \\ in a case of the Strategy of the Energy Policy of Poland \\ in perspective of the year 2050
}

Interpelacja nr 20354

do prezesa Rady Ministrów

w sprawie strategii polskiej polityki energetycznej w perspektywie do 2050 r.

Zgłaszający: Norbert Obrycki

Data wpływu: 01-03-2018

Szanowny Panie Premierze,

w opinii wielu ekspertów, w tym Seminarium Energetycznego Collegium Civitas, istnieje pilna potrzeba przyjęcia przez rząd strategii polskiej energetyki w perspektywie do roku 2050. Eksperci wskazuja, że jej brak powoduje poczucie niestabilności w zakresie bezpieczeństwa energetycznego państwa oraz może skutkować błędnymi decyzjami inwestorów lub brakiem decyzji. 
Rząd PiS nie zakończył dyskusji i nie przedstawił dotychczas żadnego strategicznego dokumentu w tym zakresie.

W kontekście dostosowania polskiej koncepcji finansowania inwestycji energetycznych do postanowień Pakietu Zimowego proszę Pana Premiera o odpowiedź na pojawiające się pytania:

Czy zasoby przemysłowe węgla kamiennego uzasadniają traktowanie go jako strategicznego źródła wytwarzania energii elektrycznej do roku 2050?

Jakie powinny być wg rządu cele strategiczne polskiej energetyki w zakresie struktury miksu energetycznego do roku 2030 i 2050?

Czy brak decyzji rządu w sprawie postawienia na energetykę rozproszoną - prosumencka, związany jest z obecnymi ograniczeniami technologicznymi Polski (brak inteligentnych sieci, smart grid oraz niewydolna infrastruktura energetyczna), czy wynika z centralistycznej wizji obecnego rządu w kwestii rozwoju polskiej energetyki?

Jaka jest aktualna koncepcja, dotycząca wykorzystania dostaw gazu skroplonego (LNG) do wytwarzania ciepła i energii elektrycznej?

Z wyrazami szacunku

Norbert Obrycki

poseł na Sejm RP 